\title{
TORWAY's POLITICAL / LingUistic / LITERARY POLICIES IN THE 1830s
}

\section{Roxana-Ema Dreve}

Babeș-Bolyai University, Cluj-Napoca, Email: dreveroxana@yahoo.com

\section{Acknowledgements}

This paper has been presented at the Seventh International Conference on Baltic and Nordic Studies in Romania, Good governance in Romania and the Nordic and Baltic countries, hosted by the Romanian Association for Baltic and Nordic Studies and Nicolae Iorga Institute of History of the Romanian Academy, București, 24-25 November, 2016.

\begin{abstract}
:
Up until 1814 Norway was a province governed from Copenhagen. After its defeat in the Napoleonic wars, Denmark was forced to give Norway to Sweden. On the political side, the direct results of these events were the establishment of the Norwegian state and the writing of the constitution. On the cultural and literary side, the union with Sweden created the condition for inquiries about national identity. But if Norway had a political identity, the foundation of a cultural identity took more time, mostly because of the lack of a unique, national language. This article focuses on some linguistic and political policies from the 1830s and their influence on literature. Important themes such as oral/written language, the conflicts between Henrik Wergeland and Johan Sebastian Welhaven, national/cultural identity, tradition/innovation will be analyzed.
\end{abstract}

\section{Rezumat:}

Până în anii 1814, Norvegia a fost o provincie guvernată din Copenhaga. După înfrângerea din Războiaele Napoleoniene, Danemarca a fost nevoită să cedeze Norvegia Suediei. Din punct de vedere politic, acest fapt a dus la înființarea statului norvegian și la redactarea și la semnarea constituției. Din punct de vedere cultural și literar, uniunea cu Suedia a creat conditiile optime pentru dezbaterea despre identitate națională. Dar dacă la acea vreme Norvegia avea o identitate politică, construirea unei identități cuturale a luat mai mult timp, în mare parte din cauza lipsei unei limbi naționale unice. Acest articol prezintă, așadar, unele aspecte lingvistice și politice din anii 1830 și influența lor în literatură. Vor fi analizate cu precădere teme importante, 
precum limbă vorbită/limbă scrisă, conflictul dintre Henrik Wergeland și Johan Sebastian Welhaven, identitate națională/culturală, tradiție/inovație.

Keywords: identity, union, nationalism, language, politics

\section{Political nationalism}

The Napoleonic Wars (1803-1815) represented one of the most striking turning points in Scandinavia. Napoleon's defeat in Russia and the Kiel treaty, from 14 January 1814, marked the beginning of another era in the history of Norway. In 1814, 400 years after Norway had been under Danish political and administrational control, Denmark had to surrender Norway to Sweden. But the Danish Crown Prince Christian Frederik repudiated the Treaty of Kiel and gathered an assembly in Eidsvoll in order to discuss the country's political and cultural future. The 112 most influential men in Norway came to Eidsvoll under the coordination of Christian Magnus Falsen and adopted a liberal constitution, the most democratic of its time, signed on the $17^{\text {th }}$ of May 1814. The main articles of the constitution focused on the separation of powers, people's sovereignty and the respect of the human, individual rights, which are now integrated in the country's politics and form the foundation of Norwegian democracy. This historical event played an essential role in Norway and led to the emergence of a patriotic feeling and a distinctive respect towards the past and the traditions it brought. Literary and history critics focused on the glorious moments of Norway's history, such as the Viking Age and the Middle Ages, becoming the basis for what was to be regarded as Norwegian identity. In the book Experiences of War and Nationality in Denmark and Norway, 1807-1815, Rasmus Glenthøy and Morten Nordhagen Ottosen underline this idea by stating that: "Scandinavism is [...] an important part of the legacy of the Scandinavia that was created in $1814^{\prime \prime}$.

Unfortunately, the independence did not last. That same year, Norway entered into a war with Sweden. King Christian Frederik had to renounce the throne in order for the country to maintain its constitution. Norway became again part of a union, this time having Karl XIV Johan (Jean-

\footnotetext{
1 Rasmus Glenthøy and Morten Nordhagen Ottosen, Experiences of War and Nationality in Denmark and Norway, 1807-1815 (United States and United Kingdom: Palgrave MacMillan, 2014), 261.
} 
Baptiste Bernadotte), one of Napoleon's officers, as king. But the Norwegian constitution and the liberty it claimed became an ideal for the population, the majority of the books, articles, presentations or speeches being based on the presence of freedom seen as "national self-determination"2.

\section{Cultural and linguistic nationalism}

The period between 1814-1830 could be regarded as a relatively peaceful period on the political side. Karl Johan's relations to Norwegians were cordial and, as stated by several critics, "[...] no union monarch since has remained as popular in Norway"3. During this period, many artists and writers created masterpieces, where the central point was represented by the fiords, the mountains, the people, Norse mythology and the historical events from 1349 to 1814.

Continuing to discuss the main political, cultural and linguistic reforms from years prior to this epoch, the general situation in the 1830s can be characterized by a national romantic debate between those who were in favour of Danish and those who supported the national movement. Moreover, Norway was a nation without a specific written language. In "Nationalism and Scandinavism in the development of the Nordic languages in the 19th century", Odd Monsson underlines the fact that "[i]n Norway the written language was the main difficulty in the development of a national identity" 4 . This contrast reflects the duality of the entire country whose elite was nevertheless influenced by Danish, while the rural population was mostly tied to folklore and oral traditions.

The two central figures of this linguistic turn from the 1830s were, the young poet, Henrik Wergeland, then 22 years old, who embraced the extravagance of the radical party and intended to enrich his poetry by using Norwegian dialect words, and Johan Sebastian Welhaven, who adopted the conservative aesthetics, supporting Danish influence in literature.

\footnotetext{
2 Ulrich Schmid, "The Norwegian Constitution and the Rhetoric of Political Poetry" in Writing Democracy: The Norwegian Constitution 1814-2014, Karen Gammelgaard and Eirik Holmøyvik, ed. (New York, Oxford: Berghahn, 2015) 87.

${ }^{3}$ Hildor Arnold Barton, Sweden and Visions of Norway: Politics and Culture, 1814-1905 (Southern Illinois University Press, 2003) 27.

4 Odd Monsson, "Nationalism and Scandinavism in the development of the Nordic languages in the 19th century", in The Nordic Languages. An International Handbook of the History of the North Germanic Languages. Oskar Bandle et alii, ed, vol. 2 (Berlin, New York: Walter de Gruyter, 2005) 1460.
} 
Johan Sebastian Welhaven grew up in Bergen and was most surely influenced in his literary works by the beautiful nature of the western Norway. His poetry inclines to describe nature's contrast and savage beauty, maintaining a nostalgic feeling towards Denmark and its literature. In Norges Dæmring, written in 1834, Welhaven criticizes his opponent, even if Wergeland's literary production, particularly his poems, like Till min gyllenlakk, or his lyric dramas, like Mennesket og Messias, placed him among the most popular writers at that time. Despite his bitterness and his rough descriptions of the low estate of Norway's development, Welhaven's national romantic desire was to bring Norway on the same cultural line as the other European countries. Later, in 1867, in Samlede Skrifter, Welhaven writes about this conflict, underlying the fact that "an age of transition, a renaissance, is always an age also of clashes and invective" 5 .

Henrik Wergeland was born in 1808, in Kristiansand, but grew up in Eidsvoll. This historical place, where Norway's constitution was signed and adopted in 1814, must have left some marks on his own perspective on the Norwegian language. Wergeland's propositions focused particularly on the gradual "norwegianisation" of Danish by the insertion of words from different dialects. When criticized by Welhaven, Henrik Wergeland received the support of his father, Nicolai, a pastor and a leading member of the Constitutional Assembly. Nicolai Wergeland criticized Norwegians' attraction towards the past, namely towards Denmark, by inventing terms such as "Danomaniac" or "Danish-minded", in order to conclude that "[ $t]$ he past [...] was not only a mirror in which the nation could see itself", but also "a battlefield and a weapon in Norway's settling of scores with Denmark $[\ldots]^{6 \prime}$.

Many scholars played an important role in the dynamics of this linguistic and cultural debate. Among them, Professor P.A. Munch distinguishes himself. Being one of the highest academic figures from his time, P.A. Munch certainly raised a lot of questions when he wrote, in 1832, the article entitled Norsk Sprogereformation, and strongly disagreed with Wergeland and the language reforms he proposed, claiming that a language is a homogeneous system that one cannot and should not fracture by introducing non-natural elements. Instead, Munch suggested either to keep

\footnotetext{
${ }^{5}$ Johan Sebastian Welhaven, Samlede Skrifter, vol. I, "Forord" (Copenhagen, 1867) quoted by Karen Larsen, History of Norway (London, Oxford: Princeton University Press, 1948) 421.

${ }^{6}$ Rasmus Glenthøy and Morten Nordhagen Ottosen, op. cit., 269.
} 
Danish as written language or, if the idea was to create a Norwegian national language, the process should not begin with the mixing of Norwegian dialects and Danish, since Denmark had a political advantage due to its growing power in the north, but with using something he called as "pure dialect".

As an answer to P.A. Munch's article, Henrik Wergeland wrote an essay entitled Om norsk sprogreformation, in 1835, where he states that Munch's method was too radical. If Norway was to have a national language, then the gradual renewing of Danish was the only way. He presented three arguments to support his theory, going from stylistics or patriotism to democracy. The main idea was that the people needed a language they could relate to and feel at ease with, a language that must be founded on the basis of Norwegian culture and specificity, a language which everyone used in everyday life. But, for the Danes and for the Norwegian elite, Danish was the written language, while the language spoken in Norway in the 1830's was considered a dialect, the mark of an inferior social class, the peasants. This is the main reason why Denmark regarded this attempt to create a national language as an intention to undermine the Danish influence in Norway. However, the precaution must have had some fundament, since, according to Glenthøy and Ottosen, several grammar schools in Norway changed "the name of the subject they taught from Danish to Norwegian in the 1830s or 1840s"7.

\section{Conclusion}

In the years following 1814, Norway lacked its own administration, entrepreneurs and institutions, since, after a long negotiation process, lasting from August 1814 to August 1815, the country accepted the union with Sweden. But the economic and political problems experienced in this period were progressively left behind as the principles of the liberal and democratic constitution adopted in 1814 have been implemented.

That is why we believe that the resurgence of Norwegian literature in the 1830s was influenced by two important events. Apart the establishment of the Oslo University in 1811, the Eidsvoll constitution created the foundation for the development of a cultural and national identity. Henrik Wergeland and Johan Sebastian Welhaven were two

\footnotetext{
7 Ibidem, 274.
} 
important authors from this period. But the Norwegian folk tales gathered by Peter Absjørnsen and Jørgen Moe played an essential role, as well.

From a linguistic point of view, the vast majority of people spoke Norwegian dialect, while still writing in Danish. But things changed in January 1836, when the young Ivar Aasen wrote a contribution to the linguistic debate from the 1830s entitled Om vort Skriftsprog, and a few years later, a grammar and a dictionary of this new language (in 1848 and 1850). In his works, Aasen joins both Wergeland and Munch's ideas and suggests that a national language is needed, but that this language cannot be created from just one particular dialect. A comparison between several dialects would be more appropriate. That is why the two different directions from the period 1830-1860 were the norwegianisation of Danish and the reconstruction of a New Norwegian written language. Started by Wergeland in the early 1830s, the idea of introducing words from Norwegian dialects into Danish (riksmål) was developed by Knud Knudsen, later named „the father of bokmall", while the creation of a New Norwegian language, landsmål, (later called nynorsk) was adopted by Ivar Aasen. The debate followed now several points, such as etymology/phonology, tradition/innovation, etc. Ivar Aasen's great contribution was that he discovered a common system one could use to unite the diverse dialects of Norway and create a bond between regions that were seen before as separated. However, landsmål had the great disadvantage of being an oral language, with no written literature, no tradition, which led to a more difficult implementation in schools and administration. While the Conservatives were in favour of Danish, the Liberals supported the new language and its principles, underlying the idea that even if Norway had a political identity, the foundation of a cultural and linguistic identity was a continuous process that started in 1814 and lasted for about one hundred years. 


\section{References:}

Barton, Hildor Arnold. Sweden and Visions of Norway: Politics and Culture, 1814-1905. Southern Illinois University Press, 2003.

Glenthøy, Rasmus, and Nordhagen Ottosen, Morten. Experiences of War and Nationality in Denmark and Norway, 1807-1815. United States and United Kingdom: Palgrave MacMillan, 2014.

Larsen, Karen. History of Norway. London, Oxford: Princeton University Press, 1948.

Monsson, Odd. 'Nationalism and Scandinavism in the development of the Nordic languages in the $19^{\text {th }}$ century'. In The Nordic Languages. An International Handbook of the History of the North Germanic Languages. Ed. Oskar Bandle et alii. Vol. 2. Berlin, New York: Walter de Gruyter, 2005, 1453-1468.

Schmid, Ulrich. 'The Norwegian Constitution and the Rhetoric of Political Poetry'. In, Writing Democracy: The Norwegian Constitution 1814-2014. Ed. Karen Gammelgaard and Eirik Holmøyvik. New York, Oxford: Berghahn, 2015, 77-92. 